\title{
Kepuasan Konsumen Pengguna Kecap Merek "S.H. D/H Siong Hin" Sebagai Icon Ekonomi Masyarakat Benteng-Tangerang
}

\author{
Sonny Santosa ${ }^{1}$ \\ Universitas Buddhi Dharma \\ snnsantosa@gmail.com
}

\begin{abstract}
Abstrak
Kepuasan konsumen merupakah hal utama yang ingin dicapai oleh pemilik usaha/bisnis. Karena dengan kepuasan konsumen inilah maka entitas keberadaan sebuah usaha/bisnis dapat terus dipertahankan. Hal inilah yang mendasari pertumbuhan icon ekonomi bagi sekelompok masyarakat. Tangerang merupakan sebuah kota administrasi yang berdiri sejak 1981, dan Produk Kecap S.H. ini berdiri di Tangerang sejak 1920 sehingga membuat kecap S.H. ini menjadi bagian penting dari sebuah produk yang turut membangun icon ekonomi bagi masyarakat Tangerang.

Penelitian ini dilakukan sebagai bagian dari analisis deskriptif atas fenomena keberadaan kecap S.H. yang telah menjadi icon pertumbuhan ekonomi khususnya bagi masyarakat BentengTangerang, 100 responden diambil sebagai sampel dalam uji penelitian ini. Uji stastistik menggunakan SPSS versi 22, dalam uji yang dilakukan dikaitkan dengan variabel citra merek dan harga yang dimana dua variabel ini didapatkan dari hasil wawancara kepada responden.

Hasil penelitian menunjukkan persamaan regresi yang didapat $Y=10,898+0,464 X_{1}+0,293 X_{2}$ Hal ini didukung dengan interpretasi nilai untuk variabel citra merek dan harga pada produk kecap S.H, mempunyai pengaruh yang cukup kuat yaitu sebesar 52\%, dengan tingkat nilai Cronbach's Alpha adalah 0,757 untuk citra merek dan 0,713 untuk variabel harga. Hal ini mempunyai interpretasi bahwa Kecap S.H. dapat dijadikan/dipertahankan sebagai salah satu icon pertumbuhan ekonomi, karena kepuasan konsumen terwujud dengan maksimal.
\end{abstract}

Kata Kunci: Kepuasan, Konsumen, Harga, Citra, Merk

\section{Pendahuluan}

Kawasan pecinan Tangerang terpusat di kawasan pasar lama Tangerang, dikawasan inilah segala lapisan masyarakat berbaur menjadi satu, tak ayal inipun menjadi pusat atau icon ekonomi masyarakat Tangerang. Komunitas mayoritas masyarakat Tangerang awalnya adalah keturunan Tionghoa yang dekat dengan areal benteng (sekarang dikenal dengan benteng makasar) oleh sebab itulah awal atau cikal bakal panggilan cina benteng (masyarakat benteng). Berdasarkan informasi yang didapatkan (Nailufar, 2018) tertera bahwa tanggal 28 Februari 1981 adalah tanggal kelahiran Kota Tangerang. Dalam perjalanan 38 tahun (tahun 2019), Kota Administrasi Tangerang menunjukan perkembangan dan pertumbuhan yang sangat pesat disegala bidang, baik dalam penyelenggaraan pemerintahan, pelaksanaan pembangunan dan pembinaan kemasyarakatan. Dinamika kehidupan perekonomian kota ditandai dengan berkembangnya unitunit usaha dan perdagangan termasuk pertumbuhan jumlah penduduk yang mencapai 921.848 jiwa, dengan laju pertumbuhan mencapai $8,27 \%$ yang diakibatkan derasnya arus urbanisasi yang pada akhirnya berpengaruh bagi kehidupan sosial-politik, budaya dan perekonomian masyarakat.

${ }^{1}$ Korespondensi: Sonny Santosa. Universitas Buddhi Dharma. Jl. Imam Bonjol No. 41 Karawaci Ilir-Tangerang. snnsantosa@gmail.com 
"Terwujudnya Kota Tangerang yang maju, mandiri, dinamis dan sejahtera dengan masyarakat yang berakhlakul karimah" adalah visi yang dicanangkan oleh Pemkot Tangerang, visi tersebut diwujudkan dengan cara meningkatkan pertumbuhan ekonomi yang berdaya saing tinggi. Seperti keunikan kota lainnya, Tangerang juga memiliki sebuah produk "kecap" merek S.H (d/h. Siong Hin) yang sudah tidak diragukan lagi oleh para wisatawan yang datang ke Tangerang.

Ibarat sebuah lingkaran, begitu pula alur proses kegiatan manusia dalam memenuhi kebutuhan hidupnya. Proses dasar dalam memenuhi kebutuhan tersebut tidak hanya didasari oleh kebutuhan tetapi juga keinginan dan daya juang/kemampuan beli untuk mendapatkan kebutuhan tersebut. Hal inilah yang membuat sebuah pengertian tentang perilaku konsumen, yaitu sebuah perilaku yang menunjukkan proses tidak hanya sebagai kata mendapatkan atau menerima sebuah produk atau jasa tetapi juga menggambarkan alur keputusan atas sebuah keputusan membeli ulang sebagai wujud dari kepuasan konsumen itu sendiri.

Dengan adanya kondisi tersebut, secara langsung kepuasan (perilaku) konsumen menjadi salah satu faktor penting dalam melihat sebuah pengaruh terhadap penguatan salah satu icon ekonomi baik yang bersifat lokal, pengaruh konsumen dan budaya merupakan salah satu dari sekian banyak faktor yang cukup mempengaruhi dalam sebuah kepuasan konsumen.

Banyak produk dan jasa yang dapat dijadikan sebagai icon pertumbuhan ekonomi masyarakat lokal, seperti produk kecap salah satunya. Dilansir dari situs (Traveloka Blog, 2018) Kecap dengan merek S.H d/h Siong Hin ternyata menduduki peringkat pertama daripada produk lainnya yang paling banyak dicari oleh wisatawan yang berkunjung ke Kota Tangerang. Kecap yang identik bewarna hitam dan mempunyai rasa kental manis ini ternyata memiliki cita rasanya sendiri karena menggunakan resep rahasia keluarga yang tetap terjaga hingga saat ini. Tak ayal, produk kecap inipun menjadi salah satu icon pertumbuhan ekonomi masyarakat lokal.

\section{Literature review}

Kepuasan konsumen bisa diartikan sebagai keuntungan sementara yang didapat oleh konsumen pada saat munculnya keputusan pembelian, pengenalan produk secara terus menerus pada pasar menambah penguatan pada posisi produk atau jasa tersebut, hal ini menggambarkan bahwa kepuasan konsumen merupakan sebuah kunci untuk selalu mendapatkan tempat yang cocok yang mewakili hasrat konsumen yang tidak terpenuhi dan memanfaatkan peluang itu secara agresif (Budiyanto, 1994)

Menurut (Kotler \& Keller, 2006) kepuasan adalah perasaan senang atau kecewa seseorang yang berasal dari perbandingan kesannya terhadap kinerja atau hasil suatu produk dan harapanharapannya. Hal ini menggambarkan bahwa jika kinerja atau hasil dari sebuah produk yang setelah dipergunakan menunjukkan dibawah harapan, maka tidak akan tercipta yang namanya kepuasan konsumen.

Kepuasan konsumen yang tercapai akan membentuk sebuah loyalitas merek, loyalitas merek ini terbentuk sebagai cerminan dari sebuah kebiasaan yang termotivasi dan sulit diubah karena telah berakar didalam sebuah pemikiran konsumen akan suatu produk. Artinya semakin baik kualitas produk maka akan semakin meningkatkan pada faktor kepuasan pelanggan.

Ketika seseorang memilih diantara dua alternatif atau lebih, perasaan tidak puas atau tidak cocok akan tidak dapat dihindarkan pemunculannya karena pada waktu konsumen membuat keputusan pembelian, konsumen akan mengetahui keuntungan dan kerugian yang berkenaan dengan keputusannya. Ketidakcocokan itu muncul setelah hampir setiap keputusan dibuat, dan untuk 
selanjutnya langkah-langkah yang diambil seseorang untuk mengurangi ketidakcocokan itu akan berbeda-beda. (Budiyanto, 1994)

\section{Metode Penelitian}

Metode statistik deskriptif dianggap cocok untuk model penelitian ini, karena penelitian ini hanya memberikan gambaran tentang masalah yang diteliti kemudian diinterpretasikan secara deskriptif tanpa membuat sebuah kesimpulan yang berlaku umum atau generalisasi (Sugiyono, 2013)

Metode yang dilakukan peneliti dalam memperoleh data yang diperlukan dalam penyusunan penelitian ini adalah dalam bentuk kuesioner dan studi literatur. Waktu dilaksanakannya penelitian ini pada bulan November tahun 2018 hingga Januari 2019 dan untuk lokasi pengambilan data dilakukan di Pasar Lama, Jalan Bakti No. 14, Pasar Lama Tangerang, lokasi penelitian ini dipilih karena dekat sebagai salah satu titik/point pengembangan ekonomi daerah oleh Pemerintah Kota Tangerang, yaitu pasar lama Tangerang yang memang berdekatan dengan lokasi pembuatan kecap merek S.H ini.

Populasi dalam penelitian ini adalah masyarakat pengunjung Pasar Lama Tangerang, sedangkan pengambilan ukuran sampel disesuaikan dengan teori (Sugiyono, 2013) yaitu ukuran sampel yang layak digunakan dalam penelitian adalah 30 sampai 500. Oleh karena itu, pengambilan sampel sebanyak 100 orang dianggap telah memenuhi persyaratan dari teori tersebut.

Dan berdasarkan urutan masalah yang telah dibahas sebelumnya, dalam mengukur kepuasan konsumen didekatkan pada vaiabel yang cenderung dijadikan sebagai keterkaitan konsumen dalam melakukan keputusan pembelian yang berulang sebagai wujud kepuasan konsumen terhadap penggunaan kecap merek S.H. Oleh karena itu, Citra merek dan harga dianggap tepat sebagai faktor/variabel yang sering dijadikan sebagai jawaban lisan oleh pembeli/pelanggan ketika menggunakan produk kecap S.H ini. Uji dilakukan dengan menggunakan alat statistik SPSS versi 22, dan beberapa ujipun dilakukan untuk melihat besaran pengaruh yang diberikan antar variabel.

\section{Hasil}

Dalam analisis data dijelaskan bagaimana data yang diperoleh harus dianalisis untuk memperoleh hasil penelitian. Dalam hal ini uji instrument yang dilakukan adalah sebagai berikut:

a. Uji Validitas

Butir pertanyaan dikatakan valid bila $r$ hitung $>r$ tabel pada nilai alpha 0.05 , apabila nilai $r$ hitung < $\mathrm{r}$ tabel, maka dikatakan tidak valid serta tidak dapat digunakan untuk analisis selanjutnya. Koefisien validasi tiap butir pertanyaan dapat dihitung dengan menggunakan rumus sebagai berikut:

$$
r \times i y=[J P \times i y] / \sqrt{(J K x i)(J K y)}\rfloor
$$

Keterangan :

$r \mathrm{x}$ iy = Koefisien korelasi antara skor butir I (Xi) dan skor totalnya (Y), atau disebut koefisien validasi butir nomor 1

$J P$ x iy $=$ Jumlah hasil perkalian antara deviasi skor nomor $1(\mathrm{Xi})$ dan deviasi skor total (y)

$J K \mathrm{x} i=$ Jumlah deviasi kuadrat skor totalnya $\left(\mathrm{x}^{2}\right)$

$J K y \quad=$ Jumlah deviasi kuadrat skor totalnya $\left(\mathrm{y}^{2}\right)$ 
b. Uji Reliabilitas

Reabilitas merupakan sebuah fungsi yang menunjukkan sejauh mana suatu alat pengukur dapat dipercaya atau diandalkan. Instrument yang realibel adalah instrument yang dapat menghasilkan hasil pengukuran (relatif) sama bila instrument itu digunakan untuk mengukur obyek yang sama pada dua atau lebih waktu yang berbeda.

$$
\begin{aligned}
r_{11}=\left(\frac{k}{k-1}\right) & \left(1-\frac{\sum \sigma_{b}^{2}}{\sigma_{t}^{2}}\right) \\
\text { Keterangan : } & \\
r_{11} & =\text { reliabilitas instrumen } \\
\mathrm{k} & =\text { banyaknya butir } \\
\sigma_{t}^{2} & =\text { varian total } \\
\sum \sigma_{b}^{2} & =\text { jumlah varian butir }
\end{aligned}
$$

c. Uji Regresi Linear Berganda

Merupakan hubungan secara linear antara dua atau lebih variabel independen dengan variabel dependen. Analisis regresi linear berganda ini dgunakan untuk mengetahui pengaruh antar variabel dalam lingkup penelitian ini. Persamaan regresi linear berganda ini yaitu:

$\mathrm{Y}=\alpha+\beta 1 \mathrm{X} 1+\beta 2 \mathrm{X} 2$

Keterangan :

Y = Variabel Y (kepuasan konsumen)

$\alpha \quad=$ Konstanta

$\beta_{1} X_{2}=$ Koefisien Regresi

$\mathrm{X}_{1}=$ Variabel X1(merek)

$\mathrm{X}_{2}=$ Variabel X2 (harga)

Proses penelitian bersifat deduktif, artinya penelitian ini dimana untuk menjawab rumusan masalah digunakan konsep atau teori sehingga dapat dirumuskan hipotesis. Hipotesis tersebut selanjutnya diuji melalui pengumpulan data lapangan. Untuk mengumpulkan data maka perlu menggunakan instrumen penelitian. Data yang telah terkumpul selanjutnya dianalisis secara kuantitatif dengan menggunakan statistik deskriptif sehingga dapat disimpulkan hipotesis yang dirumuskan terbukti atau tidak.

Hipotesis merupakan jawaban sementara erhadap rumusan masalah atau submasalah yang diajukan oleh peneliti, yang dijabarkan dari landasan teori atau kajian teori dan masih harus diuji kebenarannya (Sudaryono, 2017) pengaruh antar variabel dalam penelitian ini memiliki hipotesis sebagai berikut:

Ho : tidak ada pengaruh antar variabel terhadap kepuasan konsumen

Ha : terdapat pengaruh antar variabel terhadap kepuasan konsumen 
Dari 100 responden yang mengisi kuesioner pada penelitian ini, diketahui bahwa jenis kelamin responden yang mendominasi mengisi kuesioner ini adalah perempuan, pekerjaan terbanyak responden adalah ibu rumah tangga.

Gambar 1. Jenis Kelamin Responden

\section{Jenis Kelamin Responden}

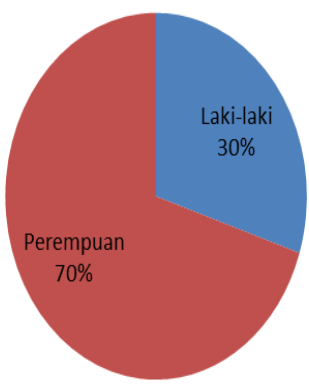

Sumber: data olahan
Gambar 2. Pekerjaan Responden

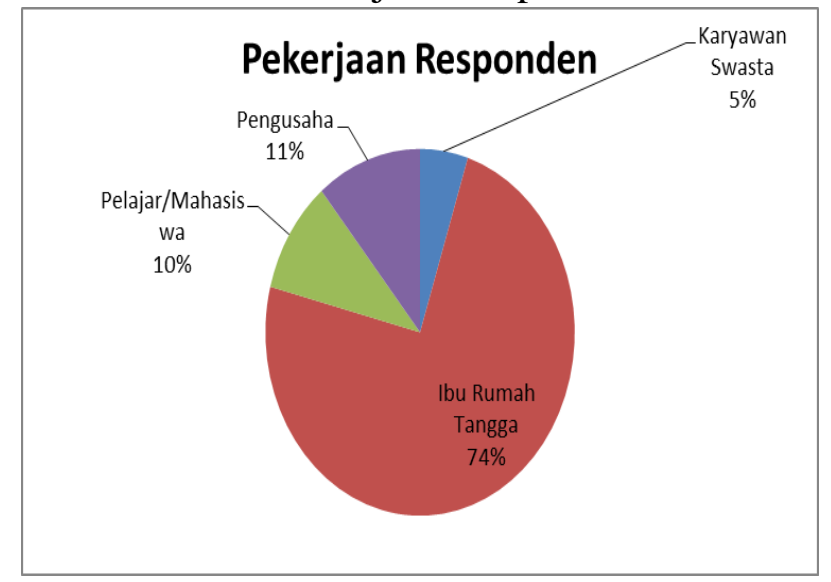

Sumber: data olahan

Lalu, untuk distribusi jawaban dari responden untuk masing-masing variabel independen adalah sebagai berikut:

Tabel 1. Reliability

\section{Uji pada variabel merek}

\section{Statistics}

\begin{tabular}{|r|r|}
\hline $\begin{array}{c}\text { Cronbach's } \\
\text { Alpha }\end{array}$ & $\begin{array}{c}\text { N of } \\
\text { Items }\end{array}$ \\
\hline, 757 & 10 \\
\hline
\end{tabular}

Tabel 2. Item-Total Statistics

\begin{tabular}{|l|r|r|r|r|}
\hline & $\begin{array}{c}\text { Scale } \\
\text { Mean if Item } \\
\text { Deleted }\end{array}$ & $\begin{array}{c}\text { Scale } \\
\text { Variance if } \\
\text { Item Deleted }\end{array}$ & $\begin{array}{c}\text { Corrected } \\
\text { Item-Total } \\
\text { Correlation }\end{array}$ & $\begin{array}{r}\text { Cronbach' } \\
\text { s Alpha if Item } \\
\text { Deleted }\end{array}$ \\
\hline Pengenalan_Merek & 36,1700 & 11,052 &, 584 &, 712 \\
Kesadaran_Merek & 36,1900 & 11,327 &, 561 &, 717 \\
Kesan_Kualitas_Merek & 36,4500 & 12,412 &, 353 &, 746 \\
Loyalitas_Merek & 36,4900 & 12,172 &, 328 &, 750 \\
Asosiasi_Merek & 36,3200 & 12,462 &, 307 &, 752 \\
Identitas_Merek & 36,3700 & 11,710 &, 445 &, 733 \\
Personalitas_Merek & 36,2900 & 12,107 &, 413 &, 738 \\
Sikap_Dan_ & 36,3900 & 11,533 &, 486 &, 727 \\
Perilaku_Merek & 36,3900 & 11,695 &, 436 &, 735 \\
Manfaat_Merek & 36,2700 & 12,623 &, 280 &, 755 \\
Keunggulan_Merek & &
\end{tabular}


Berdasarkan uji validitas yang telah dilakukan oleh peneliti, semua item pertanyaan dari masingmasing variabel mempunyai nilai $r$ hitung lebih besar daripada $r$ tabel (0.1966). nilai $r$ tabel didapat dari $\mathrm{df}=\mathrm{n}-2$ dengan pengujian 2 arah pada tingkat siginifikansi 0.05 yaitu sebesar 0.1966. korelasi nilai $r$ hitung lebih besar dari $r$ tabel. Sehingga uji validitas menunjukkan semua item pertanyaan pada variabel yang diteliti dikatakan valid karena memenuhi kriteria.

Pada tabel Reliability Statistic diatas, dapat dilihat bahwa nilai Cronbach's Alpha adalah 0,757 dengan jumlah 10 pernyataan. Jika dibandingkan dengan nilai Alpha menurut Romie Priyastama (2017 : 170) dalam bukunya "Buku Sakti Kuasai SPSS Pengolahan Data \& Analisis Data". Maka nilai Cronbach's Alpha dari variabel harga lebih besar dari standar Cronbach's Alpha $\alpha=$ 0,60, maka dapat dikatakan bahwa semua pernyataan tentang harga terbukti reliabel.

\section{Uji pada variabel harga}

Tabel 3. Reliability

\section{Statistics}

\begin{tabular}{|r|r|}
\hline $\begin{array}{l}\text { Cronbach's } \\
\text { Alpha }\end{array}$ & $\begin{array}{c}\text { N of } \\
\text { Items }\end{array}$ \\
\hline, 713 & 10 \\
\hline
\end{tabular}

Tabel 4. Item-Total Statistics

\begin{tabular}{|l|r|r|r|r|}
\hline & $\begin{array}{c}\text { Scale } \\
\text { Mean if Item } \\
\text { Deleted }\end{array}$ & $\begin{array}{c}\text { Scale } \\
\text { Variance if } \\
\text { Item Deleted }\end{array}$ & $\begin{array}{c}\text { Corrected } \\
\text { Item-Total } \\
\text { Correlation }\end{array}$ & $\begin{array}{c}\text { Cronbach' } \\
\text { s Alpha if Item } \\
\text { Deleted }\end{array}$ \\
\hline Memberikan_Daftar_ & 36,3600 & 10,758 &, 389 &, 687 \\
Harga & 36,4100 & 10,729 &, 402 &, 685 \\
Diskon_Khusus & 36,6600 & 10,813 &, 464 &, 677 \\
Harga_Sesuai_Kualitas & 36,5800 & 11,014 &, 323 &, 698 \\
Jangka_Waktu_ & 36,4000 & 11,535 &, 203 &, 718 \\
Pembayaran & 36,5400 & 10,817 &, 383 &, 688 \\
Harga_Bersaing & 36,5300 & 10,716 &, 401 &, 685 \\
Harga_Terjangkau & 36,6400 & 11,041 &, 355 &, 693 \\
Sistem_Kredit & 36,5500 & 10,472 &, 408 &, 684 \\
Keefektifan_Harga & 36,5500 & 10,715 &, 401 &, 685 \\
Potongan_Harga & & & \\
Harga_Sesuai_ & Informasi & & & \\
\hline
\end{tabular}

Berdasarkan uji validitas yang telah dilakukan oleh peneliti, semua item pertanyaan dari masingmasing variabel mempunyai nilai $r$ hitung lebih besar daripada $r$ tabel (0.1966). nilai $r$ tabel didapat dari $\mathrm{df}=\mathrm{n}-2$ dengan pengujian 2 arah pada tingkat siginifikansi 0.05 yaitu sebesar 0.1966 . korelasi nilai $r$ hitung lebih besar dari $r$ tabel. Sehingga uji validitas menunjukkan semua item pertanyaan pada variabel yang diteliti dikatakan valid karena memenuhi kriteria. 
Pada tabel Reliability Statistic diatas, dapat dilihat bahwa nilai Cronbach's Alpha adalah 0,713 dengan jumlah 10 pernyataan. Jika dibandingkan dengan nilai Alpha menurut (Priyastama, 2017). Maka nilai Cronbach's Alpha dari variabel harga lebih besar dari standar Cronbach's Alpha $\alpha=0,60$, maka dapat dikatakan bahwa semua pernyataan tentang harga terbukti reliabel.

Tabel 5. Reliability

Statistics

\begin{tabular}{|r|r|}
\hline $\begin{array}{c}\text { Cronbach's } \\
\text { Alpha }\end{array}$ & Nof Items \\
\hline, 725 & 10 \\
\hline
\end{tabular}

Sumber data: data olahan SPSS v.22

Tabel 6. Uji Reliabilitas Variabel Kepuasan Konsumen

Item-Total Statistics

\begin{tabular}{|l|r|r|r|r|}
\hline & $\begin{array}{c}\text { Scale } \\
\text { Scale Mean if } \\
\text { Item Deleted }\end{array}$ & $\begin{array}{c}\text { Corrected } \\
\text { Variance if } \\
\text { Item Deleted }\end{array}$ & $\begin{array}{c}\text { Cronbach's } \\
\text { Item-Total } \\
\text { Correlation }\end{array}$ & $\begin{array}{c}\text { Alpha if Item } \\
\text { Deleted }\end{array}$ \\
\hline Budaya & 37,2900 & 9,966 &, 394 &, 702 \\
Pengalaman & 37,3900 & 10,705 &, 212 &, 728 \\
Manfaat_Produk & 37,4300 & 10,086 &, 365 &, 707 \\
Harga & 37,4400 & 9,360 &, 492 &, 686 \\
Produk_- & 37,4200 & 10,064 &, 336 &, 711 \\
Pembanding & 37,4900 & 9,141 &, 520 &, 680 \\
Kepercayaan & 37,3500 & 9,967 &, 357 &, 708 \\
Kebanggaan & 37,3500 & 10,109 &, 348 &, 709 \\
Persepsi & 37,4400 & 9,481 &, 430 &, 696 \\
Informasi_Produk & 37,3500 & 9,664 &, 370 &, 707 \\
Ketersediaan_ & & & \\
Produk & & & \\
\hline
\end{tabular}

Berdasarkan uji validitas yang telah dilakukan oleh peneliti, semua item pertanyaan dari masingmasing variabel mempunyai nilai $r$ hitung lebih besar daripada $r$ tabel (0.1966). nilai $r$ tabel didapat dari $\mathrm{df}=\mathrm{n}-2$ dengan pengujian 2 arah pada tingkat siginifikansi 0.05 yaitu sebesar 0.1966 . korelasi nilai $r$ hitung lebih besar dari $r$ tabel. Sehingga uji validitas menunjukkan semua item pertanyaan pada variabel yang diteliti dikatakan valid karena memenuhi kriteria.

Pada tabel Reliability Statistic diatas, dapat dilihat bahwa nilai Cronbach's Alpha adalah 0,725 dengan jumlah 10 pernyataan. Jika dibandingkan dengan nilai Alpha ( Ghozali, 2011). Maka nilai Cronbach's Alpha dari variabel kepuasan konsumen mempunyai nilai tidak dibawah dari standar Cronbach's Alpha $\alpha=0,60$, maka dapat dikatakan bahwa semua pernyataan tentang kepuasan konsumen terbukti reliabel. 
Tabel. 7 Koefisien Deteminasi

Model Summary

\begin{tabular}{|c|c|c|c|c|c|c|c|c|c|}
\hline \multirow[b]{2}{*}{$\begin{array}{l}\text { Mod } \\
\text { el }\end{array}$} & \multirow[b]{2}{*}{$\mathrm{R}$} & \multirow[b]{2}{*}{$\begin{array}{c}\mathrm{R} \\
\text { Square } \\
\end{array}$} & \multirow[b]{2}{*}{$\begin{array}{l}\text { Adjusted R } \\
\text { Square }\end{array}$} & \multirow{2}{*}{$\begin{array}{c}\text { Std. Error } \\
\text { of the } \\
\text { Estimate }\end{array}$} & \multicolumn{5}{|c|}{ Change Statistics } \\
\hline & & & & & $\begin{array}{l}\text { R Square } \\
\text { Change }\end{array}$ & $\begin{array}{c}\mathrm{F} \\
\text { Change }\end{array}$ & df1 & df2 & $\begin{array}{c}\text { Sig. F } \\
\text { Change }\end{array}$ \\
\hline 1 &, $726^{\mathrm{a}}$ &, 527 &, 523 & 2,37416 &, 527 & 109,348 & & 98 & 000 \\
\hline 2 &, $759^{b}$ &, 576 & ,567 & 2,26037 & ,049 & 11,115 & & 97 & 001 \\
\hline
\end{tabular}

a. Predictors: (Constant), X1

b. Predictors: (Constant), X1, X2

Kolom R Square untuk model 1 dan 2 menunjukkan angka R Square yang disebut juga dengan koefisien determinasi. Hal ini berarti besarnya pengaruh citra merek dan harga menunjukan bahwa variabel tersebut memiliki besaran pengaruh yang bisa dikatakan kuat.

Tabel. 8 Koefisien Persamaan Regresi

Coefficients $^{\mathrm{a}}$

\begin{tabular}{|c|c|c|c|c|c|c|c|c|c|c|}
\hline \multirow[b]{2}{*}{ Model } & \multicolumn{2}{|c|}{$\begin{array}{c}\text { Unstandardized } \\
\text { Coefficients }\end{array}$} & \multirow{2}{*}{$\begin{array}{c}\text { Standardized } \\
\text { Coefficients } \\
\\
\text { Beta } \\
\end{array}$} & \multirow[t]{2}{*}{$T$} & \multirow[t]{2}{*}{ Sig. } & \multicolumn{3}{|c|}{ Correlations } & \multicolumn{2}{|c|}{$\begin{array}{c}\text { Collinearity } \\
\text { Statistics }\end{array}$} \\
\hline & $B$ & Std. Error & & & & $\begin{array}{l}\text { Zero- } \\
\text { order } \\
\end{array}$ & $\begin{array}{c}\text { Parti } \\
\text { al } \\
\end{array}$ & Part & $\begin{array}{c}\text { Toleran } \\
\text { ce } \\
\end{array}$ & $V I F$ \\
\hline 1 (Constant) & 14,928 & 2,557 & & 5,838 & ,000 & & & & & \\
\hline $\mathrm{X} 1$ &, 659 &, 063 &, 726 & 10,457 &, 000 &, 726 &, 726 &, 726 & 1,000 & 1,000 \\
\hline 2 (Constant) & 10,898 & 2,718 & & 4,010 & ,000 & & & & & \\
\hline $\mathrm{X} 1$ & ,464 &, 084 &, 511 & 5,537 & ,000 & ,726 & ,490 & ,366 &, 513 & 1,950 \\
\hline $\mathrm{X} 2$ & 293 &, 088 &, 308 & 3,334 & ,001 & ,665 &, 321 & 220 &, 513 & 1,950 \\
\hline
\end{tabular}

a. Dependent Variable: $\mathrm{Y}$

dijadikan sebagai salah satu icon pertumbuhan ekonomi masyarakat di Kota Tangerang. Hal ini dilihat dari besarannya nilai yang diuji pada variabel citra merek dan harga yang sudah melekat dihati para konsumen/pelanggan. Hasil perhitungan lanjut koefisien untuk variabel citra merek menunjukan sebesar 0,726 yang berarti mendekati 1, dimana korelasi memiliki pengaruh yang positif dan kuat. Sedangkan korelasi untuk harga menunjukan sebesar 0,665 yang berarti mendekati 1, dimana korelasi ini memiliki pengaruh yang positif dan kuat.

Meskipun pesaing-pesaing kecap S.H. didalam dunia pemasaran semakin banyak bermunculan, hal ini nampaknya tidak membuat posisi kecap S.H. ditinggalkan begitu saja oleh para pengelola kuliner khususnya, karena bagi pengelola Kecap S.H, bukanlah sekedar produk dari pikiran periklanan yang berhasil (karena memang pengelola S.H. tidak mengeluarkan biaya periklanan), lebih tepatnya, Kecap S.H. telah berhasil merefleksikan motivasi yang mendasari dan manfaat yang diharapkan yang didapatkan melalui penelitian pasar sehingga tercipta nilai kepuasan konsumen. Oleh karena itu dalam pengolahan data selanjutnya, terbentuk 


\section{Kesimpulan}

Berdasarkan hasil uji diatas, dapat disimpulkan bahwa Kecap merek S.H. d/h Siong Hin bisa dijadikan sebagai salah satu icon pertumbuhan ekonomi masyarakat di Kota Tangerang. Hal ini dilihat dari besarannya nilai yang diuji pada variabel citra merek dan harga yang sudah melekat dihati para konsumen/pelanggan. Hasil perhitungan lanjut koefisien untuk variabel citra merek menunjukan sebesar 0,726 yang berarti mendekati 1, dimana korelasi memiliki pengaruh yang positif dan kuat. Sedangkan korelasi untuk harga menunjukan sebesar 0,665 yang berarti mendekati 1, dimana korelasi ini memiliki pengaruh yang positif dan kuat.

Meskipun pesaing-pesaing kecap S.H. didalam dunia pemasaran semakin banyak bermunculan, hal ini nampaknya tidak membuat posisi kecap S.H. ditinggalkan begitu saja oleh para pengelola kuliner khususnya, karena bagi pengelola Kecap S.H, bukanlah sekedar produk dari pikiran periklanan yang berhasil (karena memang pengelola S.H. tidak mengeluarkan biaya periklanan), lebih tepatnya, Kecap S.H. telah berhasil merefleksikan motivasi yang mendasari dan manfaat yang diharapkan yang didapatkan melalui penelitian pasar sehingga tercipta nilai kepuasan konsumen. Oleh karena itu dalam pengolahan data selanjutnya, terbentuk.

\section{Daftar Pustaka}

Ghozali, I. (2011). Aplikasi Analisis Multivariate Dengan Program IBM SPSS 20. Semarang: Universitas Diponegoro.

Budiyanto. (1994). Perilaku Konsumen. Dalam R. D. James F Engel, Perilaku Konsumen. Jakarta: Binarupa Aksara.

Kotler, P., \& Keller, K. L. (2006). Manajemen Pemasaran Edisi 12. India: Prentice Hall.

Nailufar, N. N. (2018, 02 28). Kota Tangerang dalam Catatan Sejarah. Diambil kembali dari megapolitan.kompas.com:

https://megapolitan.kompas.com/read/2018/02/28/09532151/kota-tangerang-dalamcatatan-sejarah

Priyastama, R. (2017). Buku Sakti Kuasai SPSS-Pengolahan Data \& Analisa Data. Bantul: Anak Hebat Indonesia.

Sudaryono, S. (2017). Analisis Data Dan Pengujian Hipotesis. Jakarta: PT. Rajagrafindo Persada.

Sugiyono, S. (2013). Analisis Data Kuantitatif. Bandung: CV. Alfabeta Bandung.

Traveloka Blog. (2018, Oktober 10). 8 Oleh-Oleh Khas Tangerang Ini Kaya Cita Rasa Lokal. Dipetik Maret 2019, 2019, dari https://blog.traveloka.com:

https://blog.traveloka.com/banten/tangerang/8-oleh-oleh-khas-tangerang-ini-kaya-citarasa-lokal/ 